\title{
The Impact of Labor Market Inequality on the Income of Medium Industry Sector's Workers in the Palembang City-Indonesia
}

\author{
Luis Marnisah" ${ }^{1, *}$, Bernadette Robiani ${ }^{2}$, Tatang Sariman² \& Suhel Suhel ${ }^{2}$ \\ ${ }^{1}$ Indo Global Mandiri University, Palembang-Indonesia, and University of Sriwijaya, \\ Palembang, Indonesia \\ ${ }^{2}$ University of Sriwijaya, Palembang, Indonesia \\ *Correspondence: Indo Global Mandiri University, Palembang, Indonesia. E-mail: \\ luis_uigm@yahoo.co.id
}

Received: October 19, 2016 Accepted: November 4, 2016 Published: November 27, 2016

doi:10.5296/rae.v8i4.10177ＵRL: http://dx.doi.org/10.5296/rae.v8i4.10177

\begin{abstract}
This study attempts to investigate the impact of labor market Inequality on the income of medium industry sector's worker in the Palembang City-Indonesia. Using 380 respondents which covers male and female workers ranging from the age of 15 to the age of 64, this study employs a proportional stratified random sampling in determining the sampling technique. This study employs a survey method using in-depth investigation to explore all the facts acquired about the labor market inequality in the medium industry sector. The sample area includes 16 districts in the City of Palembang. The level of education, the job’s capability and the working experience are some of those factors investigated in this study. The factor of labor market inequality is focused on the wage and employment. The result reveals that apart from the level of education, the job's capability and working experience have a significant impact on the existence of labor market inequality in the medium industry sector. It can be concluded that higher level of education is inessential for the medium industry sector in Palembang City-Indonesia, and this is inline with the notion that the medium industry sector merely requires both working's capability and spesified technical skills in supporting higher productivity level. The inequality occurs in the wage and the job assigned. Furthermore, the higher the existence of labor market inequality, the lower the income acquired by the employees.
\end{abstract}

Keywords: labour market inequality, education level, capability, working experience and income level 


\section{Introduction}

Inequality is a difference in treatment to all citizens (it can be based on color, race, ethnic, economic, religious, etc.). The same is also stipulated in the ILO Convention 111 Article 1, paragraph (1), the term discrimination includes any distinction, exclusion or preference based on race, color, sex, religion, political beliefs, national origin or in the community, resulting in the loss or reduction of equality of opportunity or treatment in employment or occupation. Inequality can be found in any remuneration against female workers. Women's wages are lower than men because women are always considered as a single worker. Moreover, female employees do not receive family benefits, and social security for her husband and children. Further, the promotion is out of the question for female employees as they are always assigned in the lower position compare to male employees, who do not require high education and skills. Female employees are only assigned in a job that only requires perseverance, accuracy and neatness. These constraints may constitute a breach of the basic rights of human and may hamper the opportunities for women in the workplace. In turn, it will harm the community and the economy of Indonesia in the view of the loss of major contributions that can be given by women through employment.

Francine D.Blau and Marianne A Ferber (1986) as cited in Nurlina (1990) stated that social discrimination is the cause of the difference treatment between men and women in achieving education and specialisation in which it will ultimately affect the income received. Although Indonesian women is now much more developed compare few decades ago, but it does not affect the employment position of women in the labor market. Improving the fate of Indonesian women workers often raises many controversial and is an issue that never runs out for discussion. When women entered the workforce, the pattern of discrimination and marginalization based on the beliefs and behaviors that define women in an inferior position compared to male workers exists. The fate of Indonesian women workers depend on the government's concern for an appropriate problem solution and provide protection to its citizens. The existence of inequality and female workers' exploitation are a clear evidence that there is lack of protection of the women workers' rights in Indonesia.

Indonesian women are always interpreted as a gentle creature and have more concern on the emotional side that needs to be protected, while men are portrayed as human figures which are gallant, brave and more rational. As a result, women are associated to conduct the role of domestic particularistic nature. Meanwhile, men are associated to the universal (public) environment. This image strengthened and institutionalized in the foundations of the society as a reference act (Hubeis, AV: 2010). Further, inequality responsibility for both men and wome has shifted from traditional views to the moderate views and, it creates a new perspective on working women which resulting in the majority of women have longer working hours than the average working hours of men (Hubeis, AV: 1987). Further, men and women have the same ability to excel in the job (Hubeis, AV: 2010.74). Moreover, the emergence of the term discrimination against women is certainly not in spite of the presence of the feminist movement. The whole feminist movement departing from the awareness of discrimination, inequality, or injustice against women. Feminism as a theory of social change and development is a new phenomenon, precisely when the feminist movement responds to 
and critiques of the theory of rapid development around 1976.

Employment inequality and gender inequality are still evident as a result of low educational and health status of women demonstrated by low opportunities of women to work, as well as low access to economic resources, such as technology, information, market, credit, and capital work. Further, Daulay (2006) found that the purchasing power of women workers in Indonesia to buy their daily food needs are still very low, demand for rice $1 \mathrm{~kg}$ in 1994, female workers have to work for 221 minutes or 3.5 hours more. Meanwhile, if compared with the Philippines and Hong Kong workers they only take 55 minutes or up to an hour to work. It is seen also in the cheap food purchases, women workers in Indonesia have to work for 312 minutes, while the women laborers Thailand just 23 minutes. This means that women workers in Indonesia have to work harder than women laborers in Thailand because if you want to equate with Thailand conditions they have to work nearly 17 times that of women laborers Thailand

Parwiningrum in Khotimah (2009) suggested working women are generally classified as not the primary breadwinner families (secondary workers) having different motivations based on family socioeconomic level or education level. In the lower classes of society women entering the labor market is a must due to the economic support of the family. Instead women who come from the middle class to have an alternative choice between working or unemployed. They decided to participate work when jobs are available in accordance with the socio-economic status or level of education. As with the women who come from upper socio-economic strata, their motivation to participate in the labor market is no longer the foregone earnings, but more to the non-economic factors such as the use of the time or satisfaction needs for herself.

There are differences in gender roles between the norms prevailing in a society with the facts, and different gender roles based on the specific location. There is also a social and cultural factors that restrict the policy of gender mainstreaming in development, both derived from the norms that existed in society, or in the condition of the family / household. Different roles of women both in the allocation of time, as well as socio-economic class, hence the wisdom of uniformity in the construction of an efficient and effective action "(Elizabeth, 2007). Furtherm according Arfah (2010), health, employment tenure, work ethic, wages have a significant influence on productivity, both in the industry of small, medium and large. While the number of dependents, education, work environment and government policies have no significant influence in the small industry. In large industries all observed variables significantly influence productivity levels except education. There is a significant difference between the industrial productivity of small, medium industry, but there was no significant difference between the medium and large industries.

Discrimination is divided into two Premarket Discrimination related to human capital, and Post Market Discrimination in the form of wages and employment discrimination. Wage is categorized as inferior wages and superior wages. It can be concluded that discrimination can be inferred when a group of workers are treated inferior in terms of remuneration, access to employment, promotion, conditions of employment and wages, but they have the ability, 
education and experience of the same work with a group that was treated superiorly. In the labor market, discrimination happened in the way of wage inequality, employment type inequality, income inequality which determined the bargaining position of women in the workplace. Therefore, this study attempts to investigate the impact of labor market inequality on the income of medium industry sector in the Palembang City-Indonesia, in particular (1) the impact of education level, experience, and ability on wage given, employment, income and (2) the impact of labor market inequality on the income acquired.

\section{Literature Review}

Human resource can be interpreted as an attempt to work that can be provided in the production process. Human resource involves the human who is able to provide services or work effort. Ability to work means being able to engage in activities that have economic value, namely that these activities generate goods or services to meet the needs of society. People of working age are called labor or man power (Simanjuntak, 1985). In the production process as a basic structure for economic activity, employment is a very important factor for the labor act as economic actors, in contrast to other production factors which are passive (capital, raw materials, machinery and land). Workforce capable of acting active, able to influence and carry out the management of the other production factors are involved in the production process.

Further, the labor market is as a market that brings buyers and sellers of labor. As a seller of labor in this market are job seekers, whereas as the buyers are people/institutions that require manpower. The labor market was organized with a view to coordinating meetings between job seekers and people or institutions that need workers. In order to meet the employment needs, the labor market is perceived to provide an outlet for firms to comply. Thus not only impressed with the job seekers benefit from the existence of this market. To create the conditions that synergies between the two parties, ie between sellers and providers of workforce we need good cooperation between all parties concerned (Mizaroh, 2016).

Discrimination means derogatory connotations against certain individuals or groups are not only equal but also unfair. The difference occurs between minorities and majorities. Minorities are usually distinguished by race, ethnicity, skin color and gender. Discrimination occurs when minorities and the majority have the same capabilities but are treated differently (Kaufman; 2005; Borjas; 2005; Ehrenberg; 2003). According to Kaufman (2005), discrimination is the different between" Premarket discrimination". Premarket discrimination occurs when a person has not entered the labor market. This discrimination occurs when there is a treatment of "inferior" are derogatory treatment of minorities to education ".

Wages are the rights of workers that are accepted and expressed in the form of money as a reward from the employer or the employer to the worker / laborer assigned and paid by an employment agreement, agreements, or legislation, including allowances for workers / laborers and their families on a job and / or services that have been or will be taken by Government Regulation No. 78. Competitive markets tend to limit the impact of 
discrimination on wages. If the wages of a group of labor is lower than in other groups, for reasons that are not related to marginal productivity, then firms that do not engage in discriminatory practices will benefit greater than the companies that engage in discriminatory practices (Mankiw, 2004; 531)

In the discrimination laws, there are some important distinctions made between direct and indirect discrimination, namely direct discrimination, occurs only when a company treats a person is not good, and when gender or marital status is an important factor that influenced this decision. Eg refuse workers married woman. Furthermore, indirect discrimination is discrimination that occurs when a requirement or condition made effects / influence, and detrimental to one sex over the other. For example, regarding the marital status, the Company requires a job that requires applicants away from home for a considerable period of time. Labor market discrimination between minority and majority workers emerged from the strength of the labor market, both on the demand by the company or by the labor side deals. The core strength of the market is the company's monopoly or union is not just passive recipients of wages in the market, but have the discretion to set wages independently of competitive forces one of the possible use of market forces is set wage levels that distinguish between workers of different races, genders or groups ethnic prejudice is not the case (Kaufman, 466). Becker (1980) states that if the company will recruit employees, the company put an ad in the newspaper that resulted in many job applicants from groups of race and gender that have varying levels of education and work experience, the company will select applicants based on the characteristics that correlate with each power employment, education levels are performing in the context of the screening process, which is observed among other races.

Discrimination appears when the market offers different opportunities to similar individuals who differ only in terms of race, ethnic group, gender, age or other personal characteristics. Discrimination reflects some prejudice against certain groups in society. Although discrimination is an emotional topic that often leads to heated debate, economists have tried to study this subject objectively with the purpose of separating myth from reality (Mankiw, 2004; 532). Positive discrimination is sex discrimination positively involve direct or indirect discrimination in favor of women in situations where they are under-represented - usually at the level of seniority within the organization or work groups dominated by men. Discrimination clothing that is associated with the clothes, the court will only accept a claim if the applicant has dirugian as clothing worn. For this reason it is acceptable for employers to implement a dress code is different in male and female staff, as long as conventionality standards or norms applied socialyang same.

Employment type inequality and gender equality are still evident as a result of low educational status of women, shown by low opportunities of women to work, as well as low access to economic resources, such as technology, information, market, credit and working capital. For women Indonesia entered the era of globalization is a threat than an opportunity to improve their lives, because of competition and strict requirements to enter the workforce led to women workers who have no other choice but to accept certain jobs with low wages, although it would be demeaning them as women. Pratiwi (2009) found differences in labor 
conditions based on gender, male workers permanent status more often than women. In terms of wages, gave the same wage to the work force of men and women workers with the status of permanent workers, but for casual labor, labor wages of men was higher than women workers. Labor men get more job security than female workers. Just as job security, labor men get a guarantee of family more than the female workforce. This is due to the company's policy that assumes that men have the kind of work that are heavier and have dependents living much so that wages are higher than women. Moreover, Silvia (2009) in his research on the influence of education and income to the mobility of women workers from the industrial sector to the service sector in the district of Kuta Alam city of Banda Aceh found that education and income factors significantly affect the mobility of women workers from the industrial sector to the service sector. Any increase in education can improve the mobility of women workers at Kuta Alam subdistrict of Banda Aceh.

Indonesia still faced the problem of the labor force, mostly of low quality due to the low levels of education. Another thing that needs attention is that the labor force participation rate is high in Indonesia does not fully support the productivity, though they are working, they still get low wages, particularly female workers (Khotimah, 2009). Research on women workers in the shoe industry in Tangerang (Augustine, 2001) shows the result of which is the cost of labor (wages) male worker is $10-15$ percent of the total cost of production, but if the shoe industry employs women, labor costs can be reduced up to 5-8 percent of total production costs. In such cases, the percentage of female workers is 90 per cent of the total workers. Other cases with the same substance, was found in rural agriculture. A study of women laborers in agro export the tobacco industry in Jember (Yustin; 2005) that in order to work in the plantations, working woman earns Rp. 1650.00 per day while the male worker earns Rp. 1850.00 per day. The percentage of women workers in the case of tobacco is 80 percent.

Bruemmer (2006) and Pettinger (2006) examined the income gap in wages between women and men with variable individual factors, factors structure level and gender. It is found that women get has a lower wage compare to men. Furthermore, Claudia (2010) finds as many as 15 percent of women of America aged 25 years up to 44 years who are married reported having a job outside the home, and working women have higher income compare to men. Moreover, Lanning (2006) found that discrimination occurs in the labor market with wage based on race and gender between the workforces Differences in productivity caused by the race and gender are difficult to be adjusted to the level of wages unless particular rules are made clearly.

As a result of modernity, women experience inequitable in the employment sector which resulted in the tendency of women doing informal jobs that does not provide legal protection and it gives low wage. Besides, women subordinate factors in the social and cultural stereotypes of women as well as lower education influence discrimination existence in employment (Khotimah, 2009). Further, female workers in the apparel industry, work longer than female workers. It turns out there are no clear differences between the wages of the female workers. Saskara and Kaluge (2009) stated that there are four factors affecting female unemployment which are inflation, investment, female unemployment and the labor market. 
Elizabeth (2003) found results that only 15 people (3 percent) CEO positions held by women in 500 companies, but the number of women out of male workers in educational institutions 73.8 percent. 38.4 percent of the career development of women affected by stereotype, and gender may affect women's career progress of 31.5 percent. The results showed that for every increase of one point stereotypes, barriers to career advancement increased by 0.88 point, and for every one point increase in gender bias, the barriers to career advancement increased by 0.68 point Marginalization woman reflected in oppression and discriminatory treatment division work that kind of work, time, energy that poured out and the level of wages

\section{Research Methodology}

This study is conducted in the City of Palembang, South Sumatera, Indonesia. There 16 regions in the City of Palembang which are Kecamatan Ilir Barat II, Kecamatan Gandus, Kecamatan Seberang Ulu I, Kecamatan Kertapati, Kecamatan Seberang Ulu II, Kecamatan Plaju, Kecamatan Ilir Barat I, Kecamatan Bukit Kecil, Kecamatan Ilir Timur I, Kecamatan Kemuning, Kecamatan Ilir Timur II, Kecamatan Kalidoni, Kecamatan Sako, Kecamatan Sematang Borang, Kecamatan Sukarami, Kecamatan Alang-alang Lebar. This study employs a survey method using in-depth interviews and questionnairre which is aimed at all workers in the medium enterprises sector in the City of Palembang. There are 380 respondents which spans from all those 16 regions.

Education level, ability, experience, labor market inequality (discrimination), wage, employment type and income are all variables employed in this study. As mentioned that this study attempts to investigate (1) the impact of education level, experience, and ability on wage given, employment, income and (2) the impact of labor market inequality on the income acquired. Therefore, two equations are presented as follow:

$$
\begin{aligned}
& D=\alpha+\beta_{1} X_{1}+\beta_{2} X_{2}+\beta_{3} X_{3}+e \\
& Y=\alpha+\beta D
\end{aligned}
$$

Labor market inequality is denoted as $\mathrm{D}$, and it contains wage/employment type/income. Income is denoted as $\mathrm{Y}$. Education, ability and experience are denoted as $\mathrm{X}_{1}, \mathrm{X}_{2}$ and $\mathrm{X}_{3}$ subsequently.

\section{Finding}

The findings are divided into two sections; first, the findings for the first equation and; second, the findings for the second equation. Table 1 presents the impact of education, ability and experience on wage (first equation) 
Table 1. Regression Result

\begin{tabular}{|c|c|c|c|c|c|c|}
\hline \multicolumn{7}{|c|}{ Coefficients } \\
\hline & & $\begin{array}{r}\text { Unstanc } \\
\text { Coeffi }\end{array}$ & $\begin{array}{l}\text { ardized } \\
\text { cients } \\
\end{array}$ & $\begin{array}{l}\text { Standardized } \\
\text { Coefficients }\end{array}$ & & \\
\hline \multicolumn{2}{|c|}{ Model } & $\mathrm{B}$ & Std. Error & Beta & $\mathrm{t}$ & Sig. \\
\hline \multirow[t]{4}{*}{1} & (Constant) & .807 & .381 & & 2.119 & .035 \\
\hline & Education & .027 & .053 & .026 & .510 & .611 \\
\hline & Ability & .316 & .140 & .171 & 2.253 & .025 \\
\hline & Experience & .257 & .107 & .145 & 1.592 & .044 \\
\hline
\end{tabular}

a. Dependent Variable: Wage

As can be seen on Table 1, apart from education, ability and experience have a significant impact on wage. It can be concluded that education is not important in the medium enterprises sector. The ability and skills of the employee are of important in this medium enterprises sector. The more skilled and capable workforce is the higher wages they get. Elizabeth (2013) found that only 3 percent of the CEO positions held by women in 500 companies, in educational institutions 73.8 percent. Further as much as 38.4 percent of women's career development is influenced by stereotype, and gender may affect women's career progress of 31.5 percent. The results showed that for every increase of one point stereotypes, barriers to career advancement increased by 0.88 point, and for every one point increase in gender bias, the barriers to career advancement increased by 0.68 point Marginalization woman reflected in oppression and discriminatory treatment division work that kind of work, time, energy that poured out and the level of wages.

This study proves that experiences have a significant effect on labour market inequality, with the difference in the number of work experience possessed manpower will certainly put the workforce at the management level that is higher than the labor force who have little work experience. Likewisem Setiawan (2010) indicated that work experience has a significant positive effect on the job seeking process. Means that job seekers who have work experience will have less time used to seek work than those who do not have experience. Further, the result is in line with Lanning (2006) that found discrimination occurs in the labor market with wage based on race and gender are integrated among workers and have positive and significant impact on the productivity of workers, differences in wage rates, the level of productivity between whites with black. Differences in productivity is caused by race, gender and factors in the long term it is difficult to adjust the level of wages unless made of clear rules.

Table 2 presents the impact of education, ability and experience on labour market inequality (employment type) for the first equation. 
Table 2. Regression Result

\begin{tabular}{|c|c|c|c|c|c|c|}
\hline \multicolumn{7}{|c|}{ Coefficients } \\
\hline & & $\begin{array}{r}\text { Unstanc } \\
\text { Coeffi }\end{array}$ & $\begin{array}{l}\text { ardized } \\
\text { cients } \\
\end{array}$ & $\begin{array}{l}\text { Standardized } \\
\text { Coefficients }\end{array}$ & & \\
\hline \multicolumn{2}{|c|}{ Model } & $\mathrm{B}$ & Std. Error & Beta & $\mathrm{t}$ & Sig. \\
\hline \multirow[t]{4}{*}{1} & (Constant) & .203 & .172 & & 1.179 & .239 \\
\hline & Education & .022 & .024 & .048 & .930 & .353 \\
\hline & Ability & .148 & .063 & .178 & 2.330 & .020 \\
\hline & Experience & .113 & .054 & .123 & 1.297 & .037 \\
\hline
\end{tabular}

a. Dependent Variable: employment type

As can be seen on Table 2 that the result for labour market inequality (employment type) is similar to the result for labour market inequality (wage) in Table 1 which is only education has no significant impact on labour market inequality (employment type). Meanwhile, the ability and experience have a significant impact on labour market inequality (employment type). The result is in line with Fatmawati (2013), Kadek and Setyadhi (2013), and Nina (2015) which found that ability and experience have a significant impact on labour market inequality. Furthermore, this is in line with the opinion of Kaufman (2005) that the discrimination is different between "Premarket discrimination". Premarket discrimination occurs when a person has not entered the labor market. This discrimination occurs when there is a treatment of "inferior" are derogatory treatment of minorities to pursue education as an example, a family would differentiate the treatment for the boy and his daughter in continuing education. Boys will be schooled as high in the hope to be ready to compete when entering the job market, while the only female children schooled at a lower level.

This section provides the result for the second equation which is the impact of labour market inequality (wage) on income.

Table 3. Regression Result

\begin{tabular}{|c|c|c|c|c|c|c|}
\hline \multicolumn{7}{|c|}{ Coefficients } \\
\hline \multirow{2}{*}{\multicolumn{2}{|c|}{ Model }} & \multicolumn{2}{|c|}{$\begin{array}{l}\text { Unstandardized } \\
\text { Coefficients }\end{array}$} & \multirow{2}{*}{$\begin{array}{c}\begin{array}{c}\text { Standardized } \\
\text { Coefficients }\end{array} \\
\text { Beta } \\
\end{array}$} & \multirow[b]{2}{*}{$\mathrm{t}$} & \multirow[b]{2}{*}{ Sig. } \\
\hline & & $\mathrm{B}$ & Std. Error & & & \\
\hline \multirow[t]{2}{*}{ Wage } & (Constant) & 3.043 & .075 & & 40.404 & .000 \\
\hline & Wage & .091 & .034 & .137 & 2.695 & .007 \\
\hline
\end{tabular}

a. Dependent Variable: Income

As can be seen in Table 3 that the result reveals that wage has a significant impact on workers' income, and this is in line with Du Puis Bruemmer (2006) that found the income gap in wages between women and men with variable individual factors, factors structure level and 
gender stated that women get jobs and lower pay, as well as free time 3.8 hours fewer women than men. Further, this is also similar to Pettinger (2006) stated that women are still experiencing gender discrimination in income and employment position. Moreover, Pratiwi (2009) stated that there are differences in labor conditions based on gender. Labor men get more job security than female workers. Just as job security, labor men get a guarantee of family more than the female workforce. This is due to the company's policy that assumes that men have the kind of work that are heavier and have dependents living much so that wages are higher than women.

Table 4 presents the result for the second equation which is the impact of labor market inequality (employment type) on income.

Table 4. Regression Result

\begin{tabular}{lrrrrrr}
\hline \multicolumn{7}{c}{ Coefficients } \\
\hline & \multicolumn{2}{c}{$\begin{array}{l}\text { Unstandardized } \\
\text { Coefficients }\end{array}$} & \multicolumn{2}{c}{$\begin{array}{c}\text { Standardized } \\
\text { Coefficients }\end{array}$} & & \\
\cline { 2 - 5 } Model & \multicolumn{1}{c}{ B } & \multicolumn{1}{c}{ Std. Error } & Beta & \multicolumn{1}{c}{ T } & \multicolumn{1}{c}{ Sig. } \\
\hline 1 & (Constant) & 2.824 & .027 & & 103.146 & .000 \\
& Employment & .212 & .075 & .145 & 2.842 & .005 \\
\hline
\end{tabular}

a. Dependent Variable: Income

As can be seen in Table 4 that employment type has a significant impact on the workers' income, and the result is in line with the research (Chiplin and Slone; 1982) who found that the male labor force by age (prime age) are concentrated in high-wage jobs having the characteristics of stable and better career prospects which is referred to as primary jobs. However, this is contradictory with the provisions of ILO (Geneva, 2003) which states that the elimination of discrimination in employment through the promotion of equality of treatment and opportunity is not about the disappearance of all the differences in the labor market. The purpose of this policy is to ensure that the differences that exist in the job market reflects a free choice in the selection of work, lack of bias in the way of determination and achievement awards, and kesempatanyang equal in obtaining and maintaining the skills relevant to the labor market. "Doyle ( 2003) on Discrimination in the labor market matcing found that productivity minority workers more than non-minority workers in several companies, where wages are lower than wages minority non-minorities. Standard equilibrium wages lower minority pointed to the fact that the productivity of the workers at the company's minority takes or over a longer period. The unemployment rate is 6.3 higher blacks than whites 3.3\%, lower wages blacks than whites.

\section{Conclusion}

The result reveals that apart from the level of education, the job's capability and working 
experiences have a significant impact on the existence of labor market inequality in the medium industry sector. It can be concluded that higher level of education is inessential for the medium industry sector in Palembang City-Indonesia, and this is inline with the notion that the medium industry sector merely requires both working's capability and spesified technical skills in supporting higher productivity level. The inequality occurs in the wage and the job assigned. Furthermore, the higher the existence of labor market inequality, the lower the income acquired by the employees. Further, stipulated requirements of selection is required to minimize the labor market inequality and the tests given should be done professionally.

\section{References}

Arfah, A. (2010). Analisis Produktivitas pekerja wanita etnis bugis, makasar dan toraja pada sektor industri di makasar sulawesi selatan, Disertasi, Univ Brawijaya Malang.

Becker, G.S. (1980). Human Capital; A Teoritical and Empirical Analysis, With Special Preference to Education. Chicago: The University of Chicago Press.

Blau, F.D., \& Ferber, M. S. (1986). The Economic of women, men, and work. Frentice-Hall, Englewood Clifls, New Jersey.

Borjas, G. J. (2005). Labor Economics (3 ${ }^{\text {rd }}$ Edition). Boston: McGraw-Hill.

Claudia, G. (2010). Memahami Gender Gap, sebuah sejarah ekonomi perempuan amerika new york; oxford University Press.

Daulay, H. (2006). Buruh Perempuan di Industri Manufaktur Suatu Kajian dan Analisis Gender. Fisip USU.

Doyle. (2003). Discrimination in the matcing labor market. University of Maryland, College Park, Thesis.

Du Puis L. B. (2006). The effect of the household division of labor on the income of men and womenthesis proquest information and learning company 300 north zeeb road p.o.box 1346 ann arbor, MI 48106-1346

Ehrenberg, R.G., \& Smith, R.S. (2003). Modern Labor Economics: Theory and Public Policy. International Edition. Boston: Addison Wesley.

Elizabeth, R. (2007). Pemberdayaan wanita mendukung strategi gender maintreaming dalam kebijakan pembangunan pertanian di pedesaan. Forum penelitian Agro Ekonomi, 25(2).

International Labor Organization (ILO). (1999). Action Plan on Gender Maintreaming and Gender Equality (Rencana Aksi Pengarusutamaan Gender dan Kesetaraan Gender).

Kaufman, B.E., \& Hotchkiss, J.L. (2003). The Economics of Labor Markets. Australia: Thomson South Western.

Khotimah, K. (2009). Diskriminasi gender terhadap perempuan dalam sektor pekerjaan, 
Journal studi gender dan anak YIN Yang, 4(1), 158-180.

Lanning, A. J. (2006). Three essays in labor market discrimination, Dissertation, The University of Michigan.

Mizaroh. (2016). Retrieved from https://mizaroh.wordpress.com/esdm.dan.ketenagakerjaan/ diskriminasi .pasar.tenaga.kerja

Nurlina Tarmizi. (1990). Ekonomi Ketenagakerjaan. Edisi ke-dua. Palembang: Unsri Press.

Pettinger, M. (2006). Are women still experiencing gender discrimination in income and employment position? Why the equal pay act may be enough to close the pay gap. Thesis.

Pratiwi Linda. (2009). Marginalisasi Perempuan Dalam Industri dan Pengaruhnya Terhadap Kesejahteraan Keluarga Pekerja, Institut Pertanian Bogor.

Saskara, I. A. N., \& Kaluge, D. (2009). Analisis faktor faktor yang mempengaruhi pengangguran perempuan. Journal of Indonesian Applied Economics, 3(2), 111-120.

Silvia, V. (2009). Beberapa Faktor yang mempengaruhi tingkat partisipasi angatan kerja wanita di propinsi aceh, Jurnal Ekonomi dan Bisnis, 8(1), 77-91

Simanjuntak, P. J. (1985). Pengantar Ekonomi Sumberdaya Manusia. Jakarta : Lembaga Penerbit Fakultas Ekonomi UI.

Yustin. (2005). Penelitian tentang buruh wanita pada agro industri tembakau ekspor di Jember.

\section{Copyright Disclaimer}

Copyright for this article is retained by the author(s), with first publication rights granted to the journal.

This is an open-access article distributed under the terms and conditions of the Creative Commons Attribution license (http://creativecommons.org/licenses/by/3.0/). 